\title{
QUALITY OF CHICKEN SAUSAGE COATED BY TRANSGLUTAMINASE-CROSSLINKED BOVINE SPLIT HIDE GELATIN AND SOY PROTEIN ISOLATE EDIBLE FILM DURING CHILLED STORAGE
}

\author{
Dwi Wulandari ${ }^{1 *}$, Yuny Erwanto ${ }^{2)}$, Yudi Pranoto ${ }^{3)}$, Rusman $^{2)}$, Sugiyanto ${ }^{4)}$ \\ ${ }^{1)}$ Department of Leather Processing Technology, Polytechnic ATK, Jl. Ring Road \\ Selatan,Glugo, Panggungharjo, Sewon ,Bantul, Yogyakara 55188 Indonesia \\ ${ }^{2)}$ Departement of Animal Products Tecnology, Faculty of Animal Science, Gadjah Mada \\ University, Jl. Fauna No. 3, Bulaksumur Yogyakarta 55281 Indonesia \\ 3) Faculty of Agricultural Technology, Gadjah Mada University Yogyakarta Jl. Flora No.1 \\ ,Bulaksumur Yogyakarta,55281 Indonesia. \\ 4) Department of Leather Products Processing Technology, Polytechnic ATK, Jl. Ring Road \\ Selatan,Glugo, Panggungharjo, Sewon ,Bantul, Yogyakara 55188 Indonesia \\ E-mail: dwiw2313@gmail.com
}

Submitted 13 January 2020; Accepted 15 June 2020

\begin{abstract}
This research aims to determine the physical properties and the bacterial counts of chicken sausages that were given an edible coating made from a combination of bovine split hide gelatin and soy protein isolate with the addition of the enzyme transglutaminase during chilled storage. The parameters observed included, $\mathrm{pH}$, moisture, protein content, weight loss, tenderness, and the bacterial counts. Data were analyzed with a completely randomized design (CRD) factorial pattern $4 \times 4$ with three replications. The first factor was the level of edible coating $0 \%, 5 \%, 10 \%$, and $15 \% \mathrm{w} / \mathrm{vol}$. The s factor was the storage time at $10^{\circ} \mathrm{C}$ which was $0,5,10$, and $15 \mathrm{~d}$. The results showed the $\mathrm{pH}$ and moisture during storage decreased, while the protein content, weight loss, tenderness, and the bacterial count sausages increased. Increasing the level of edible coating to hold sausage weight loss, while the $\mathrm{pH}$ and bacterial count of chicken sausage decrease. Increase the level of edible coating adds to the water content, protein content, and sausage tenderness. The use of a combined edible coating of bovine split hide gelatin and soy protein isolate with the addition of the enzyme transglutaminase to $15 \%$ could maintain the quality of chicken sausage based on national standard during 15 dof chilled storage BSN-3820-2015.
\end{abstract}

Keywords: Edible coating; bacterial counts; gelatin; bovine split hide; sausage 


\section{INTRODUCTION}

Sausage is one of the processed meat products that are very popular with the people of Indonesia since 1980 (Astawan, 2008). This elliptical and red or brown food is made from meat, it can be chicken, beef, lamb, fish or pork. Sausages contain fairly high water which is a maximum of $67 \%$ and a minimum of $13 \%$ protein (BSN-38202015), so it is very easy to experience damage especially by microbes. Many attempts have been made to make sausage shelf life, but these efforts often do not pay attention to safety and proper consumption. An example of an attempt to make a sausage shelf life longer is to use hazardous materials such as formaldehyde or borax. Besides that, the use of plastic as packaging is inseparable from daily life, including for food packaging. This happens because plastic is a food packaging material that is cheap, easy to obtain, and durable.

However, addictive substances in plastics break down easily in fat and heat, so that if they are contaminated with food that enters the body accumulatively it can cause cancer and hormonal changes. The use of plastic that is not according to the requirements will cause various health problems because it can trigger cancer and tissue damage in the human body (carcinogenic) (Karuniastuti, 2013). Efforts to extend the shelf life of sausages that pay more attention to food safety and proper consumption are needed. One way is to apply edible coating on the chicken sausage. Edible coating or edible film is a thin layer used to coat food (coating), or placed between components that serve as a barrier to mass transfer such as water, oxygen, and fat or function as a carrier for food additives and can directly inhibit microbial contamination (Krochta and Johnson, 1997). The edible film, one of which can be made from bovine split hide gelatin, which is a byproduct of the industrial tanning leather in the from liming flash leather section (Wulandari et al., (2017) ${ }^{2}$; (Hastutiningrum, 2009). Edible films from gelatin or collagen have good potential. Any type of protein can be used as an edible film because its chemical structure has good coating properties. The advantage of using edible film for food packaging is to extend the shelf life of the product and not pollute the environment because the edible film can be eaten directly with the packaged product (Chambi \& Grosso, 2006). Consumer awareness of food products for health and the environment becomes a consideration for conducting research. This research provides information on the quality of chicken sausage in cold storage for long periods by utilizing the potential of bovine split hide combined with soy protein isolate using cross-linking agent transglutaminase as raw material for an edible film, so it can replace plastic packaging.

Research by Liao et al (2009) succeeded in making edible films from a combination of gelatin bovine type B with soy protein isolate by the heating process. Hasdar (2011) can make edible films from chicken feet skin gelatin and soy protein isolate by heating. An enzyme recently used as a cross-linking agent between two proteins is the enzyme transglutaminase. The effect of transglutaminase treatment on film properties has been investigated in the modification of soybean flour and bovine split hide gelatin (Wulandari et l $^{1}$., 2017). Cross-linking can also be applied to glutamine and lysine from two different
*Corresponding author:

Dwi Wulandari

Email: dwiw2313@gmail.com

Department of Leather Processing Technology,

Polytechnic ATK, Jl. Ring Road Selatan,Glugo,

Panggungharjo, Sewon ,Bantul, Yogyakara 55188

Indonesia
How to cite:

Wulandari, D., Erwanto, Y., Pranoto, Y., Rusman., Sugiyanto. (2020). Quality of Chicken Sausage Coated by Transglutaminase-Crosslinked Bovine Split Hide Gelatin and Soy Protein Isolate Edible Film During Chilled Storage. Jurnal Ilmu dan Teknologi Hasil Ternak, 15 (3), 142-151 
types of proteins so that heteropolymers are formed (Davalos-Saucedo et al., 2018). Yayli et al (2017) added the enzyme transglutaminase to the film from chicken meat protein can improve the physical and chemical properties of edible film.

The result of research Wulandari et al $(2017)^{1}$ showed that the addition of transglutaminase enzyme as cross-linking to edible films made from bovine split hide gelatin and soy protein isolates caused the film to become more elastic, homogeneous and compact. The application by transglutaminase-crosslinked bovine split hide gelatin and soy protein isolate edible film of chicken sausage coated to determine the physical properties of sausages and the level of microbial contamination during chilled storage.

\section{MATERIAL AND METHODS}

\section{Materials}

Materials of this research were combination gelatin (bovine split hide gelatin + Soy Protein Isolate (SPI) + transglutaminase enzyme), glycerol, aqua dest, 70\% alcohol, agar media (Merck), chicken meat, and sausage spices. The tools used in the research were glassware, Petri dishes, Hanna brand $\mathrm{pH}$ meters, ovens (Memmert, refrigerators (Lovibond), electric scales (Sartorius), Copper (Table fine cutter AK series 14115), Stuffer (Sausage stuffer model SSf-SH5), Penetrometer (KIC) brand warner Bratzler Meat shear model 235, Colony counter brand Stuart Scientific.

\section{Making edible film solution}

The procedure for making a combination of edible film based gelatin solution is done after getting gelatin through the process of extracting bovine split hide and then adding soy protein isolate and the enzyme transglutaminase. The extracted product is then poured on Teflon and dried in an oven at $50^{\circ} \mathrm{C}$ for 3 dto produce gelatin sheets. Gelatin sheets are blended with a blender to produce a combination of gelatin powder. Gelatin powder was dissolved in distilled water so that the concentrations were $5 \%, 10 \%, 10 \%(\mathrm{w} / \mathrm{v})$ and heated in a water bath at $55^{\circ} \mathrm{C}$ for $30 \mathrm{~min}$, then added $20 \%$ glycerol from the combined gelatin used, after being mixed it was heated for $10 \mathrm{~min}$. Then cooled to room temperature.

\section{Making chicken sausage.}

Milled chicken is added with spices in comparison (chicken meat, tapioca flour, skim milk, garlic, salt, pepper, coriander, STTP, angkak, cooking oil, water : 62,5 ; 17,$5 ; 2,5 ; 1,75 ; 2,0 ; 0,5 ; 0,25 ; 0,25 ; 0,5 ; 0,5$; $11,75)$. Chicken meat that has been ground with salt and followed by other seasonings then stir until homogeneous. The dough is then chopped for $30 \mathrm{~min}$ while adding ice water. The homogeneous dough is stuffed in sausage casings using stuffer, then steamed for $30 \mathrm{~min}$.

\section{Methods \\ Procedure}

The finished chicken sausage is removed from the sleeve and allowed to cool at room temperature. The Application of film by coating (coating) on chicken sausage refers to the method used (McHugh \& Senesi, 2000) that has been modified. The sausage is dipped in an edible film solution for $5 \mathrm{~min}$, then drained for $2 \mathrm{~min}$ in a sieve. Dipping is done 2 times so that all parts of the sausage are evenly coated. Sausages are then transferred to a tray and dried with a hair drier for $30 \mathrm{~min}$ with turning over. Furthermore, each sausage is weighed and put in a plastic box according to the number of treatments to be stored at $10^{\circ} \mathrm{C}$ for 5 , and $15 \mathrm{~d}$. The next step is physical and chemical testing $(\mathrm{pH}$, moisture content, protein content, weight loss, sausage tenderness, and bacterial counts of chicken sausages). The flow chart of edible film application in sausages by coating is shown in Figure 1.

\section{Sausage pH}

Sausage weighing $2 \mathrm{~g}$ is chopped and put into a glass beaker, then added $18 \mathrm{~mL}$ of distilled water, stirred and homogenized 
with the stirrer. The sausage $\mathrm{pH}$ was determined using a $\mathrm{pH}$ meter that was previously calibrated using a $\mathrm{pH} 4$ and $\mathrm{pH} 7$ solution. Measurement of sausage $\mathrm{pH}$ by inserting a $\mathrm{pH}$ meter into a beaker glass containing a sausage solution and waiting until the $\mathrm{pH}$ is constant.

\section{Sausage moisture content}

Determination of moisture content using a digital oven (Memmert). Determination of moisture content based on differences in sample weight before and after drying. The empty cup is roasted at $100-105^{\circ} \mathrm{C}$ for $1 \mathrm{~h}$, cooled in a desiccator for $30 \mathrm{~min}$, weighed. Samples (small pieces) $\pm 0.5 \mathrm{~g}$ put in a cup, roasted at a temperature of $100-105^{\circ} \mathrm{C}$ for $24 \mathrm{~h}$ until the weight is constant.

\section{Sausage protein content}

Determination of crude protein content in a sample by multiplying the 6.25 multiplier factor from the $\mathrm{N}$ produced. This method is based on the oxidation of the nitrogen gelatin component with sulfuric acid, to obtain ammonium sulfate.

After the solution is made alkaline with $\mathrm{NaOH}$, ammonium is distilled and captured with boric acid to form salts. Determining the amount of distilled ammonium is carried out by titration of salt formed with $\mathrm{HCl}$. Determining the amount of distilled ammonium is carried out by titration of salt formed with $\mathrm{HCl}$.

\section{Weight loss}

Sausages that have been stored in a refrigerator at $10^{\circ} \mathrm{C}$ for 5,10 , and 15 dare placed in a petri dish that is known to be weighed, as well as for $0 \mathrm{~d}$ (not stored). Sausage weight loss value is weighing on a petri dish for $0,5,10$, and $15 \mathrm{~d}$.

\section{Sausage tenderness}

The tenderness measurement was carried out using a Penetrometer brand K.I.C with a weight of $10 \mathrm{~g}$. The sample is placed under the penetrator needle where the pointer is put at number 0 . The tenderness can be known by reading the number on the tool divided by the sausage circle area $\left(2.54 \mathrm{~cm}^{2}\right)$.

\section{Bacterial counts sausage}

The bacterial counts test was carried out by the plate count method. Nutrient media agar for sterilizing pour in $\pm 15 \mathrm{ml}$ sterile Petri dishes in a warm condition. $1 \mathrm{~g}$ of sample is inserted into a test tube containing $9 \mathrm{ml}$ of sterile aqua dest as dilution $10^{-1}$.

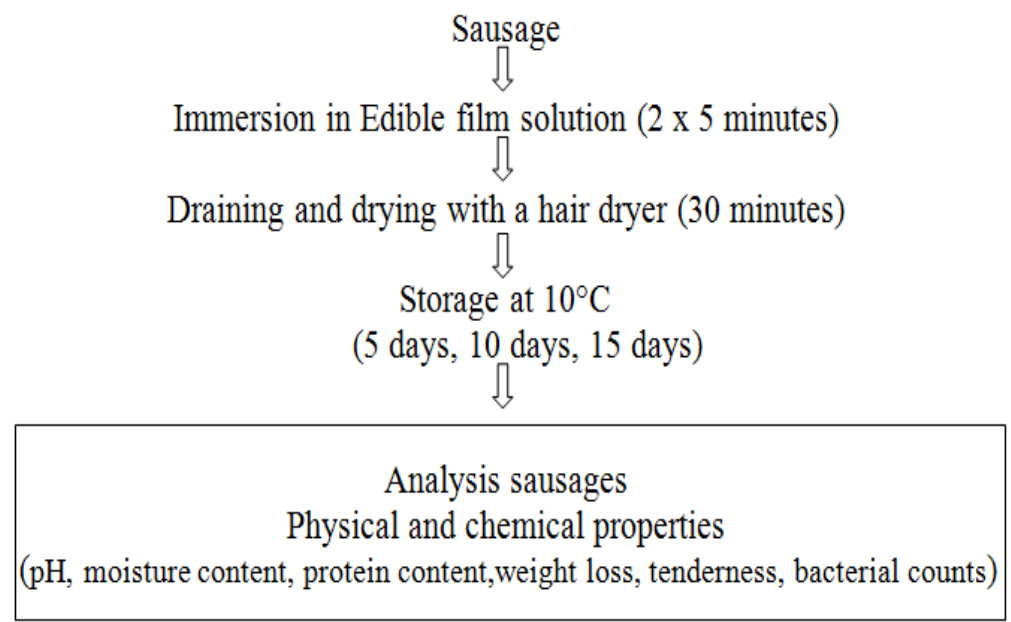

Figure 1. Flow chart of a combination edible film application on the chicken sausage. 
Then take one $\mathrm{ml}$ and put in the s test tube as a $10^{-2}$ dilution and so on until a $10^{-4}$ dilution. Taken $1 \mathrm{ml}$ planted into Petri dishes at dilutions $10^{-3}$ and $10^{-4}$, in a shake. The medium is allowed to stand until solidified and put in an incubator at $37^{\circ} \mathrm{C}$ for $2 \times 24 \mathrm{~h}$. The number of colonies is counted by the colony counter. Colonies that count are Petri dishes with a total of 30-300 colonies counted (Fardiaz, 1993).

\section{Design analysis}

The research used a completely randomized $4 \times 4$ factorial design with three replications. The first factor was the level of edible film that is $0 \%, 5 \%, 10 \%$, and $15 \%$ and the s factor was the storage time at $10^{\circ} \mathrm{C}$ which is $0,5,10$, and $15 \mathrm{~d}$. Data obtained from the result of subsequent studies analyzed by one way analysis of variance (ANOVA). It was continued to Duncan's Multiple Range Test (Steel and Torrie, 1993) if the treatment indicated a significant effect at a probability level of 5\%. The SPSS Statistics v.20 (IBM SPSS Statistics) software was used for the statistical processing of data.

\section{RESULTS AND DISCUSSION}

\section{Sausage pH}

Results of analysis of variance Table 1 shows that differences in gelatin concentration and storage time significantly $(\mathrm{P}<0.05)$ on the $\mathrm{pH}$ value of sausages. The storage time factor has a significant effect on sausage $\mathrm{pH}$. The $\mathrm{pH}$ value of sausages with $15 \%$ edible coating on storage for up to 15 dstill stands at $\mathrm{pH} 6.17$ which means the $\mathrm{pH}$ of sausages is still near neutral. The increased level of the edible coating causes the sausage $\mathrm{pH}$ to be lower because with the increasing percentage of edible coating level the density is getting tighter to coat the surface of the sausage so that less oxygen is released from the sausage (Yanti et al., 2008). The reduced oxygen content causes the growth of lactic acid bacteria to increase so the accumulation of lactic acid in sausages causes the $\mathrm{pH}$ to drop (Aryanta,
2007). Increasing and decreasing the $\mathrm{pH}$ of chicken sausage is related to bacterial growth. The decrease in $\mathrm{pH}$ is associated with the contamination of lactic acid bacteria. The decrease in $\mathrm{pH}$ during storage is due to the activity of psychrophilic bacteria which decreases carbohydrates and produces organic acids, especially lactic acid during carbohydrate fermentation (Mudawaroch \& Zulfanita, 2012).

\section{Moisture content}

Sausage moisture levels decrease during storage. Results of analysis of variance Table 1 showed that there was a significant difference between storage time and edible film level $(\mathrm{P}<0.05)$ on the moisture content of chicken sausages. The addition to storage time decreases sausage moisture content. This is due to evaporation during storage. According to Hadiwiyoto (1993) during storage, there will be a desiccation process that is the evaporation of water at low temperatures resulting in a decrease in moisture content. Alsuhendra et al (2011) explained, during the storage period there was a loss of water and other volatile components in the process of respiration (evaporation of water, gas, and energy) and transpiration, namely the release of water in the form of water vapor.

Moisture content increases with increasing concentration of edible film. According to Soeparno (2005), edible film coatings can maintain the binding capacity of water in meat because the edible film casings contain protein so that the protein can bind to the free water contained in sausages. The results of Darmajana et al (2018) research on melons coated with edible film, during storage, the movement of moisture content from cut melons into the surrounding air will be held back by the coating material. Furthermore, the moisture content of the melon will make equilibrium with the edible film moisture content.

The value of the sausage moisture content of the research ranged from 53.92 $63.12 \%$. These results are not much different from the results of the study of Muttaqien $e t$ 
al ( 2013) which uses edible film from broiler chicken skin shank gelatin as sausage edile coating, which is $53.39-58.07 \%$ and are still within the requirements of BSN-013820-1995. Maximum sausage quality requirements $67 \% \mathrm{w} / \mathrm{w}$.

Table 1. Physical and Microbiological Analysis of Chicken Sausages Coated in Edible Film at Chilled Storage

\begin{tabular}{|c|c|c|c|c|c|c|}
\hline \multirow[t]{2}{*}{ Parameters } & \multirow{2}{*}{$\begin{array}{c}\text { Edible } \\
\text { coating } \\
(\%)\end{array}$} & \multicolumn{4}{|c|}{ Storage } & \multirow[t]{2}{*}{ Average } \\
\hline & & 0 & 5 & 10 & 15 & \\
\hline & 0 & $6.40 \pm 0.04^{\mathrm{c}}$ & $6.18 \pm 0.02^{b}$ & $6.39 \pm 0.03^{c}$ & $6.41 \pm 0.02^{\mathrm{d}}$ & $6.35 \pm 0.03^{r}$ \\
\hline \multirow[t]{3}{*}{$\mathrm{pH}$} & 5 & $6.38 \pm 0.05^{\mathrm{c}}$ & $6.23 \pm 0.05^{\mathrm{b}}$ & $6.26 \pm 0.03^{b}$ & $6.15 \pm 0.04^{b}$ & $6.26 \pm 0.04^{\mathrm{q}}$ \\
\hline & 10 & $6.24 \pm 0.02^{\mathrm{b}}$ & $6.19 \pm 0.01^{\mathrm{b}}$ & $6.25 \pm 0.03^{\mathrm{d}}$ & $6.19 \pm 0.03^{c}$ & $6.22 \pm 0.02^{p}$ \\
\hline & 15 & $6.23 \pm 0.01^{\mathrm{b}}$ & $6.25 \pm 0.01^{\mathrm{b}}$ & $6.43 \pm 0.04^{b}$ & $5.94 \pm 0.01^{\mathrm{a}}$ & $6.21 \pm 0.02^{\mathrm{p}}$ \\
\hline Average & & $6.31 \pm 0.03^{z}$ & $6.21 \pm 0.02^{y}$ & $6.33 \pm 0.03^{z}$ & $6.17 \pm 0.03^{x}$ & \\
\hline Moisture & 0 & $62.86 \pm 0.54^{\mathrm{g}}$ & $58.33 \pm 1.5^{\mathrm{b}}$ & $6.52 \pm 0.55^{\mathrm{b}}$ & $53.92 \pm 1.36^{\mathrm{a}}$ & $56.26 \pm 1.14^{\mathrm{p}}$ \\
\hline \multirow[t]{3}{*}{$(\%)$} & 5 & $62.03 \pm 0.14^{\mathrm{f}}$ & $59.81 \pm 0.18^{c}$ & $59.35 \pm 1.02^{\mathrm{c}}$ & $58.92 \pm 3.51^{\mathrm{c}}$ & $59.36 \pm 1.57^{q}$ \\
\hline & 10 & $60.90 \pm 0.87^{\mathrm{d}}$ & $61.97 \pm 0.4^{\mathrm{f}}$ & $61.62 \pm 0.85^{\mathrm{e}}$ & $60.32 \pm 0.15^{\mathrm{c}}$ & $61.30 \pm 0.47^{\mathrm{r}}$ \\
\hline & 15 & $60.14 \pm 0.08^{c}$ & $63.12 \pm 0.20^{\mathrm{h}}$ & $62.48 \pm 0.08^{\mathrm{g}}$ & $62.24 \pm 0.18^{f}$ & $62.61 \pm 0.15^{r}$ \\
\hline Average & & $61.48 \pm 0.41^{\mathrm{w}}$ & $60.81 \pm 0.57^{x}$ & $59.99 \pm 0.63^{x}$ & $58.85 \pm 1.3^{y}$ & \\
\hline Protein & 0 & $12.75 \pm 0.52^{\mathrm{a}}$ & $12.97 \pm 0.28^{\mathrm{a}}$ & $13.02 \pm 0.02^{\mathrm{c}}$ & $13.28 \pm 0.04^{\mathrm{c}}$ & $13.01 \pm 0.22^{\mathrm{p}}$ \\
\hline \multirow[t]{3}{*}{ content $(\%)$} & 5 & $12.86 \pm 0.30^{\mathrm{a}}$ & $12.68 \pm 0.23^{\mathrm{a}}$ & $13.24 \pm 0.26^{\mathrm{b}}$ & $13.84 \pm 0.11^{\mathrm{e}}$ & $13.16 \pm 0.23^{p}$ \\
\hline & 10 & $13.23 \pm 0.01^{\mathrm{a}}$ & $13.11 \pm 0.06^{\mathrm{c}}$ & $13.35 \pm 0.02^{\mathrm{d}}$ & $14.00 \pm 0.06^{\mathrm{e}}$ & $13.42 \pm 0.04^{\mathrm{q}}$ \\
\hline & 15 & $13.36 \pm 0.01^{\mathrm{c}}$ & $13.85 \pm 0.05^{\mathrm{e}}$ & $14.00 \pm 0.04^{\mathrm{e}}$ & $14.11 \pm 0.16^{\mathrm{e}}$ & $13.83 \pm 0.31^{\mathrm{r}}$ \\
\hline Average & & $13.15 \pm 0.16^{w}$ & $13.05 \pm 0.21^{\mathrm{w}}$ & $13.40 \pm 0.09^{x}$ & $13.83 \pm 0.09^{y}$ & \\
\hline Weight & 0 & $1.47 \pm 0.09^{a}$ & $8.31 \pm 1.31^{\mathrm{d}}$ & $18.53 \pm 1.49^{\mathrm{g}}$ & $12.66 \pm 1.47^{\mathrm{e}}$ & $10.24 \pm 1.09^{\mathrm{r}}$ \\
\hline loss & 5 & $1.37 \pm 0.12^{\mathrm{a}}$ & $6.29 \pm 0.43^{c}$ & $8.38 \pm 0.58^{\mathrm{d}}$ & $14.45 \pm 1.43^{\mathrm{f}}$ & $7.62 \pm 0.64^{\mathrm{q}}$ \\
\hline \multirow[t]{2}{*}{$(\%)$} & 10 & $1.22 \pm 0.09^{\mathrm{a}}$ & $4.86 \pm 0.61^{b}$ & $6.27 \pm 0.73^{c}$ & $15.17 \pm 0.59^{f}$ & $6.88 \pm 0.51^{\mathrm{q}}$ \\
\hline & 15 & $1.09 \pm 0.07^{\mathrm{a}}$ & $4.08 \pm 0.22^{b}$ & $5.00 \pm 0.43^{b}$ & $13.77 \pm 1.68^{\mathrm{e}}$ & $5.99 \pm 0.60^{\mathrm{p}}$ \\
\hline Average & & $1.29 \pm 0.09^{w}$ & $5.89 \pm 0.64^{\mathrm{x}}$ & $9.55 \pm 0.81^{y}$ & $14.01 \pm 1.29^{\mathrm{z}}$ & \\
\hline Tenderness & 0 & $0.38 \pm 0.05^{\mathrm{a}}$ & $0.33 \pm 0.02^{\mathrm{a}}$ & $0.34 \pm 0.02^{\mathrm{a}}$ & $0.38 \pm 0.05^{\mathrm{a}}$ & $0.36 \pm 0.04^{p}$ \\
\hline \multirow[t]{3}{*}{$\left(\mathrm{kg} / \mathrm{cm}^{2}\right)$} & 5 & $0.47 \pm 0.00^{\mathrm{b}}$ & $0.47 \pm 0.00^{\mathrm{b}}$ & $0.48 \pm 0.01^{b}$ & $0.48 \pm 0.02^{\mathrm{b}}$ & $0.48 \pm 0.01^{\mathrm{q}}$ \\
\hline & 10 & $0.52 \pm 0.02^{\mathrm{c}}$ & $0.52 \pm 0.02^{\mathrm{c}}$ & $0.58 \pm 0.05^{\mathrm{e}}$ & $0.59 \pm 0.00^{\mathrm{e}}$ & $0.55 \pm 0.02^{\mathrm{r}}$ \\
\hline & 15 & $0.61 \pm 0.02^{\mathrm{e}}$ & $0.57 \pm 0.02^{\mathrm{d}}$ & $0.59 \pm 0.04^{\mathrm{e}}$ & $0.68 \pm 0.02^{\mathrm{f}}$ & $0.61 \pm 0.03^{\mathrm{s}}$ \\
\hline Average & & $0.50 \pm 0.02^{\mathrm{w}}$ & $0.47 \pm 0.02^{\mathrm{w}}$ & $0.49 \pm 0.03^{\mathrm{w}}$ & $0.53 \pm 0.02^{x}$ & \\
\hline Bacterial & 0 & $34 \pm 1.53^{\mathrm{c}}$ & $35 \pm 2.52^{\mathrm{c}}$ & $51 \pm 2.08^{\mathrm{d}}$ & $58 \pm 2.65^{\mathrm{f}}$ & $45 \pm 2.20^{\mathrm{r}}$ \\
\hline counts & 5 & $29 \pm 0.58^{b}$ & $31 \pm 1.15^{\mathrm{e}}$ & $50 \pm 5.86^{d}$ & $53 \pm 2.52^{\mathrm{e}}$ & $41 \pm 2.53^{r}$ \\
\hline$\left(x 10^{4}\right.$ & 10 & $23 \pm 1.16^{a}$ & $24 \pm 2.52^{\mathrm{a}}$ & $48 \pm 7.21^{\mathrm{d}}$ & $54 \pm 4.04^{\mathrm{e}}$ & $37 \pm 3.73^{\mathrm{q}}$ \\
\hline koloni) & 15 & $18 \pm 0.58^{a}$ & $45 \pm 7.64^{\mathrm{d}}$ & $20 \pm 0.58^{a}$ & $50 \pm 2.00^{\mathrm{d}}$ & $33 \pm 2.70^{p}$ \\
\hline Average & & $26 \pm 0.96^{w}$ & $28 \pm 1.69^{w}$ & $49 \pm 5.70^{x}$ & $54 \pm 2.80^{y}$ & \\
\hline
\end{tabular}

Different superscript in the same row and columns showed significant differences $(\mathrm{P}<0.05)$

\section{Protein content}

The results showed that the longer storage and increasing levels of edible film sausage protein levels had increased. The results of the analysis of variance of sausage protein levels showed a significant difference $(\mathrm{P}<0.05)$ along with the increase in storage time and the increase in edible film levels (Table 1). Increased levels of sausage protein during storage in the results of this research could occur due to reduced levels of sausage moisture. During storage, the sausage moisture level has decreased. This causes sausages to be denser and drier so that increasing protein levels.

According to Utami et al (2017) that sausages that lose a lot of water will increase their protein levels. The increase in sausage protein levels by increasing the level of the edible film is due to the basic ingredient of the edible film is soy protein isolate which is the purest form of soy protein and gelatin which is the hydrolysis of a bovine split hide collagen protein (Wulandari et al., 2019). 
One of the sausage quality parameters can be seen from the level of sausage protein. Sausage protein levels during the storage period are still high. According to BSN3820-2015 the minimum protein content in sausage meat is $13.0 \%(\mathrm{w} / \mathrm{w})$. The level of chicken sausage protein research results ranged from $13.14-13.42 \%$. These results still meet the meat sausage quality requirements.

\section{Weight loss}

One function of an edible film is to resist the migration of water vapor. Loss of moisture in sausage products causes the product to become hard and wrinkled. The weight loss rate shows the ability of edible film to protect packaged products from the migration of compounds contained in the material so that quality is maintained. The smaller the weight loss, the better the packaging (Estiningtyas, 2010).

Table 1 shows that the weight loss of sausages that are not coated with the edible film is greater than that coated with edile film. This means that the increased level the edible film decreases the percentage of weight loss. This is because the edible film lining the sausage is getting denser after all the cross-linking between the soy protein isolate and the gelatin of bovine split hide more so that the evaporation of water is also getting smaller. The longer the storage the greater the sausage weight loss. Sausage weight loss is affected by water loss during storage. This is influenced by the ability of proteins to bind water. The more water held by the protein the less water comes out so that the value of the weight loss decreases.

The results of this research are in line with research (Alsuhendra et al., 2011) which states that the shrinkage of the fruit during storage is relatively small if given an edible coating because the edible coating can prevent water loss from the fruit. The edible coating is a good barrier against water and oxygen. It also can control the rate of respiration, therefore it is widely used to package fresh fruit products and other food products, such as confectionery products, frozen meat and chicken, sausages, seafood products, and semi-wet food (Pade, 2019).

\section{Sausage tenderness}

The results of the analysis of variance showed that differences in gelatin level and storage time were significantly different $(\mathrm{P}<0.05)$ on sausage tenderness. Factors that influence sausage tenderness are sausage meat protein, sausage binding tool, and sausage edible coating. The results showed the longer the storage, the tenderness was increasing. Utami et al (2017) explained that increasing the storage time would increase damage to hydrolyzed proteins, so the chemical bonds in the meat loosened. This results in a loose protein structure. Utami et al (2017) further explained the decline in the value of sausages during storage, because the components of the binding tissue in fish sausages have been overhauled due to microorganism activity, thus affecting the texture of fish sausages to be rather soft. According to (Mega, 2010) sausage tenderness level is determined by the density of the matrix structure that is formed in the cooking process, besides the addition of the type of binder used can also affect the level of sausage tenderness.

The results of the analysis of the concentration of edible film gave a significant difference $(\mathrm{P}<0.05)$ to the tendency of chicken sausages. The more the concentration of edible film tenderness increased. This increase is caused because an edible film can resist the migration of water vapor. Increasing the concentration of edile film, the greater the density of the film which causes the moisture content to evaporate smaller so that the packaged product is softer. Sausage tenderness is also caused by a decrease in $\mathrm{pH}$ during storage. According to Muchtadi and Ayustaningwarno (2010), during storage, there was a decrease in $\mathrm{pH}$ because microorganisms activity degraded carbohydrates into simple compounds. With the breakdown of carbohydrates (starch, pectin or cellulose), the food can experience softening. 


\section{Total Bakteri Sosis}

Variance analysis results from Table 1 show that the level of edible film and storage time significantly affect bacterial counts sausage. The effect of edible film level shows that sausages without edible film have more bacterial counts than sausages given edible film, meaning that the more edible film levels the bacterial counts are reduced.

This is due to the increased density of edible film which causes contact with free air getting smaller, so the level of pollution is low. Said (2011) explains edible film can inhibit the migration of water vapor from the environment to the protected material so that the length of sausage storage is long. Ahmad et al (2012) also reported that gelatin film combined with lemongrass essential oil could inhibit 2 phases of microbial growth in snapper slices. According to Miskiyah et al (2015), that edible antimicrobial film based on chicken leg gelatin applied to meat can inhibit S.aureus and E.coli.

Table 1 shows that the longer the storage the bacterial counts are increasing. Increasing bacterial counts is caused by the presence of psychrophilic bacteria that are resistant to low temperatures (Sompie, 2014). According to Said (2011) states that gelatin can be used as a growth medium for microorganisms because it is a component that is rich in protein compounds and can be broken down by microorganisms.

Gelatin also has the same function as agar, so it is possible that increasing the shelf life indicates an increase in bacterial activity in sausage products. The bacterial counts of sausage results of research for 15 dwith $15 \%$ edible coating as much as $50 \mathrm{x}$ $10^{4}$ colonies, this still meets the meat sausage quality standards according to BSN3820-2015 namely $10^{5}$ colonies/g.

\section{CONCLUSION}

The application of a combination of edible film bovine split hide gelatin and soy protein isolate with the addition of the enzyme transglutaminase as an edible coating on chicken sausage during chilled storage has a significant effect on $\mathrm{pH}$, moisture content, protein content, weight loss, tenderness of sausage and bacterial counts of chicken sausage. The use of $15 \%$ edible coating with a storage temperature of $10^{\circ} \mathrm{C}$ for $15 \mathrm{~d}$, the quality of sausages still meets the quality requirements of meat sausages namely BSN-3820-2015.

\section{REFERENCES}

Ahmad, M., Benjakul, S., Sumpavapol, P., \& Nirmal, N. P. (2012). Quality changes of sea bass slices wrapped with gelatin film incorporated with lemongrass essential oil. International Journal of Food Microbiology, 155(3), 171-178. https://doi.org/10. 1016/j.ij foodmicro.2012.01.027

Alsuhendra., Ridawati., \& Santoso, A. I. (2011). Pengaruh penggunaanedible coating terhadap susut bobot,ph, dan karakteristik organoleptik buah potong pada penyajian hidangan Desertasi. Fakultas Teknik Universitas Negeri, Jakarta.

Aryanta, I. W. R.( 2007). Peranan Bakteri Asam Laktat dalam Industri Pengolahan Bahan Pangan.Dalam: Proseding Orasi Ilmiah Guru Besar Universitas Udayana tahun 1991 2005. Badan Penjaminan Mutu.Universitas Udayana,Denpasar.

Astawan, M. (2008). Bahaya Laten Sepotong Sosis.

BSN (Badan Standarisasi Nasional). (2015). Sosis Daging. Standar Nasional Indonesia- 3820. Jakarta.

Chambi, H., \& Grosso, C. (2006). Edible films produced with gelatin and casein cross-linked with transglutaminase. Food Research International, 39(4), 458-466. https://doi.org/10.1016/j.fo odres.2005.09.009

Darmajana, D. A., Afifah, N., Solihah, E., \& Indriyanti, N. (2018). Pengaruh pelapis dapat dimakan dari karagenan terhadap mutu melon potong dalam penyimpanan dingin. Agritech, 37(3), 
280. https://doi.org/10.22146/agritech .10377

Dávalos-Saucedo, C. A., Rossi-Márquez, G., Regalado-González, C., AlonzoMacías, M., \& Di Pierro, P. (2018). Application of transglutaminase crosslinked whey protein-pectin coating improves egg quality and minimizes the breakage and porosity of eggshells. Coatings, 8(12). https://doi.org/10.33 90/coatings8120438.

Estiningtyas, H.R. (2010). Aplikasi edible film maizena dengan penambahan ekstrak jahe sebagai antioksidan alami pada coating sosis sapi. Thesis. Program Studi Tehnologi Hasil Pertanian, Fakultas Pertanian Universitas Sebelas Maret, Surakarta.

Fardiaz, S. (1993). Analisis Mikrobiologi Pangan. PT. Raja Grafindo Persada, Jakarta.

Hadiwiyoto, S. (1993). Teknologi Pengolahan Hasil Perikanan. Penerbit Liberty, Yogyakarta.

Hasdar, M. (2011).Karakteristik edible film yang diproduksi dari kombinasi gelatin kulit kaki ayam dan soy protein.Tesis. Fakultas Peternakan Universitas Gadjah Mada, Yogyakarta

Hastutiningrum, S. (2009). Utilization of the split leather tanning industry for making glue with collagen hydrolysis. Jurnal Teknologi, 2(2), 208-212.

Karuniastuti, N. (2013). Bahaya plastik terhadap kesehatan dan lingkungan. Swara Patra: Majalah Pusdiklat Migas, 3(1), 6-14.

Krochta, J. M, and Johnson, C.M. (1997). Edible and biodegradable polymer film challenges and opportunities. J.Food Technology. 51: 61-74.

Liao, P., Jiang, P., Bai, H. Y., Jiang, J. Q., Chen, M. Q., Yang, C., \& Liu, X. Y. (2009). Preparation and physical properties of soy protein isolate and gelatin composite films. Gongneng Cailiao/Journal of Functional Materials, 40(2), 291-294. https://doi. org/10.1016/j.foodhyd.2006.09.001.

McHugh, T. H., and Senesi, E. (2000).
Apple Wraps: A Novel method to improve the quality and extend the shelf life of fresh-cut apples. Journal of Food Science, 65(3), 480-485. https://doi.org/10.1111/j.1365-2621.2 000.tb16032.x

Mega, O. (2010). Pengaruh substitusi susu skim oleh tepung kedelai sebagai binder terhadap beberapa sifat fisik sosis yang berbahan dasar surimi-like kerbau. Jurnal Sain Peternakan Indonesia, 5(1), 51-58. https://doi.org /10.31186/jspi.id.5.1.51-58

Miskiyah., Juniawati., \& Iriani, E. S. (2015). Potensi edible film antimikroba sebagai pengawet daging potential of antimicrobial edible film as meat preservatives. Buletin Peternakan, 39(2), 129-141.

Muchtadi, T. R. dan Ayustaningwarno, F. (2010). Teknologi Proses Pengolahan Pangan. Alfabeta, Bandung.

Mudawaroch, R. E., dan Zulfanita. (2012). Kajian berbagai macam antioksidan alami dalam pembuatan sosis. Surya Agritama, I(1), 71-84.

Muttaqien, A. T., Nuhriawangsa, A. M. P., \& Swastike, P. W. (2013). Sifat fisik edible film dari gelatin shank ayam broiler dan pengaruh penggunaannya terhadap cemaran mikroba sosis daging sapi dengan masa simpan yang berbeda.Tropical Animal Husbandry. 2(1), 15-20.

Pade, S. W. (2019). Edible coating pati singkong ( Manihot utilissima Pohl) terhadap mutu nenas terolah minimal selama penyimpanan. Juurnal Agercolere. 1(1), 13-18.

Said, M.I. (2011). Optimasi proses produksi gelatin kulit kambing sebagai bahan baku edible film untuk bahan pengemas obat (kapsul). Desertasi. Program Pascasarjana Fakultas Peternakan Universitas Gadjah Mada, Yogyakarta.

Soeparno. (2005). Ilmu dan Teknologi Daging. Cetakan ke-3 .Gadjah Mada University Press, Yogyakarta

Sompie, M. (2014). Karakterisasi edible film 
berbahan dasar gelatin kulit babi sebgai pengemas daging babi. Desertasi. Program Pascasarjana Fakultas Peternakan Universitas Gadjah Mada, Yogyakarta.

Steel, R.G, \& Torrie, J.H. (1993). Principle and Procedure of Statistic. Mc. Graw Hill Book Company. Inc New York.

Utami, R., Agustini, T.W., \& Amalia, U. (2017). Aplikasi edible coating semi refined karaginan terhadap daya simpan sosis ikan kurisi (nemipterus nematophorus) pada penyimpanan suhu dingin. J. Peng. \& Biotek, 6(2), 24-32.

Wulandari, D., Erwanto, Y., Pranoto, Y., \& Rusman, R. (2017) ${ }^{1}$. The properties of edible film derived from bovine split hide gelatin with isolated soy protein using various levels of glycerol in the presence of transglutaminase. Buletin Peternakan, 41(3), 319. https://doi. org/10.21059/buletinpeternak.v41i3.2 4329

Wulandari, D., Erwanto,Y., \& Pranoto, Y. $(2017 .)^{2}$. Increased physical and morphological properties of edible film bovine split hide gelatin with the addition of SPI and transglutaminase. The 7th International Seminar on Tropical Animal Production, 446450.

Wulandari, D., Erwanto,Y., Pranoto, Y., \& Yuliatmo, R. (2019). Improvement of bovine split hide gelatin quality by addition of soy protein isolate using transglutaminase enzyme. Tropical Animal Science Journal. (December). 42 (3). 237-244. https://doi.org/10. 5398/tasj.2019.42.3.237

Yanti, H., Elfawati., \& Hidayati. (2008). Kualitas daging sapi dengan kemasan plastik PE (polyethylen) dan plastik PP (Polypropylen). Jurnal Peternakan, 5(1), 22-27.

Yayli, D., Turhan, S., \& Saricaoglu, F. T. (2017). Edible packaging film derived from mechanically deboned chicken meat proteins: Effect of transglutaminase on physicochemical properties. Korean Journal for Food Science of Animal Resources, 37(5), 635-645. https://doi.org/10.5851/kos fa.2017.37.5.635 